\title{
KONSEPTUAL PEMANFAATAN MODEL MEDIA WEB MOODLE DALAM PEMBELAJARAN PPKN DI SEKOLAH MENENGAH ATAS
}

\author{
Fathikah Fauziah Hanum \\ Universitas Negeri Yogyakarta, Yogyakarta, Indonesia \\ fauziahh20@gmail.com
}

\begin{abstract}
This paper aims to describe the form of Moodle web media for Civic Education learning in Senior High School and how it is used in learning. Based on previous research that some students need web-based learning media, it is necessary to determine the concept of the type of media and how the steps. This research is descriptive and this is done by literature review. The results of the study show that the concept of the model of media used in web-based media development is digitalbased multimedia because the characteristics of Moodle's web media in it contain a combination of various media and connected with the internet network. Whereas the learning model is blended learning in the form of face-to-face mixed learning and elearning in time and proportion of the use of mixed learning is flexible and online learning is used as a compliment.
\end{abstract}

Keywords: blended learning, web media, multimedia

\begin{abstract}
Abstrak
Tulisan ini bertujuan menggambarkan bentuk media web Moodle untuk pembelajaran PPKn di Sekolah Menengan Atas serta bagaimana pemanfaatannya dalam pembelajaran. Berdasarkan penelitian sebelumnya bahwa beberapa siswa membutuhkan media pembelajaran berbasis web, maka perlu menentukan konsep jenis model media dan bagaimana langkah-langkahnya. Penelitian ini adalah penelitian deskriptif dan hal ini dilakukan dengan kajian pustaka. Hasil kajian menunjukkan bahwa konsep model media yang digunakan dalam pengembangan media berbasis web adalah multimedia berbasis digital karena karakteristik dari media web moodle ini di dalamnya berisi kombinasi dari berbagai media dan terhubng dengan jaringan internet. Sedangkan model pembelajarannya adalah blended learning yang berupa pembelajaran campuran tatap muka dan e-learning namu waktu dan porposi penggunaan pembelajaran campuran adalah bersifat fleksibel serta pembelajaran online digunakan sebagai pelengkap.
\end{abstract}

Kata kunci: blended learning, media web, multimedia 


\section{PENDAHULUAN}

Pembelajaran adalah proses interaksi antara peserta didik, guru dan lingkungan belajar untuk mencapai tujuan pembelajaran. Setiap komponen pembelajaran memmiliki peran dalam hal ini. Komponen itu antara lain guru, siswa, media dan sebaganya. Kalau salah satu komponen kurang baik maka tujuan pembelajaran juga kurang bisa tercapai. Dalam tulisan ini penulis fokus pada permasalahan yang terjadi pada pemanfaatan media pembelajaran. Media pembelajaran terus berkembang mengikuti perkembangan teknologi, seperti menurut Abdulhak, I. \& Darmawan, (2015, hal. 5) bahwa sejumlah pencapaian dalam teknologi mendorong terjadinya pergeseran paradigma dalam pendidikan. Proses pembelajaran dewasa ini sudah bergeser kepada dominasi peran dan hasil adopsi dari inovasi kajian komunikasi digital atau komunikasi bermedia dengan memanfaatkan teknologi digital.

Ketika teknologi berkembang ke arah digital atau memanfaatkan internet maka media juga telah bergerak dalam dunia digital. Dunia digital tidak hanya menampilkan satu jenis media saja, misal audio saja atau visual saja, tetapi telah menggabungkan dari beberapa jenis media tersebut atau sering disebut dengan istilah multimedia. Penting bagi pengembang multimedia untuk memiliki pemahaman yang jelas tentang bagaimana informasi yang disajikan dalam berbagai media digital disimpan, dimanipulasi dan diingat oleh peserta didik (Alty, Al-Sharrah, \& Beacham, 2006). Hal tersebut mendorong upaya-upaya pembaharuan dalam pemanfaatan hasil-hasil teknologi dalam proses pembelajaran, seperti guru mampu memanfaatkan alat atau media yang sesuai dengan perkembangan teknologi tersebut (Kustandi \& Sutjipto, 2011, hal. 6).

Adanya media internet mempermudah warga belajar untuk mengakses ke berbagai sumber informasi, termasuk halaman web. Melalui halaman web ini, maka warga belajar dapat mentransformasikan informasinya kepada orang lain sehingga membentuk suatu jaringan atau komunitas belajar. Selain itu juga mempermudah siswa dalam pembelajaran cepat dan mudah memahami materi belajar yang berupa informasi. Namun dalam pemanfaatannya terjadi beberapa permasalahan.

Permasalahan pemanfaatan media pembelajaran dalam pendidikan sebagaimana yang dicatat oleh Wilbur Schramm yang dikutip oleh Sadiman, Rahardjo, Haryono, \& Harjito (2008) menyatakan dari sekian banyak kasus penerapan media teknologi pendidikan $75 \%$ terjadi di negara dunia ketiga atau negara yang sedang berkembang. Permasalahan tersebut antara lain kurangnya minat guru dalam memanfaatkan media pembelajaran. Hal ini bisa disebabkan karena guru kesulitan mengikuti teknologi yang sedang berkembang.

Permaasalahan selanjutnya adalah ketidaktertarikan peserta didik pada media pembelajaran yang digunakan. Terdapat sejumlah media pembelajaran yang kurang optimal keadaannya, seperti; jumlah dan komponennya kurang, kualitasnya buruk, dan media yang tidak accessible (mudah didapat/diakses). Ketidak tertarikan peserta didik terhadap media adalah dengan menunjukkan sikap 'ogah-ogahan' dan tidak semangat untuk melakukan proses pembelajaran jika menggunakan media pembelajaran tertentu. Sehingga apabila media tersebut dipaksakan untuk digunakan mengakibatkan posisi siswa terbebani, dari merasa terbebani tersebut siswa tidak akan tertarik karena sebelum memanfaatkan media tersebut, siswa sudah harus dihadapkan masalah-masalah untuk menggunakan dan memahami media yang digunakan.

\section{JURNAL KEWARGANEGARAAN}


Di abad ke 21 ini siswa sudah tidak asing lagi dengan pemanfaatan internet menurut Parker Siswa zaman sekarang tampak terlibat dalam banyak tugas praktik setiap harinya, dari cetak ke film ke bentuk multimodal seperti situs web dan video permainan. Siswa tinggal di dunia media yang rata-rata menghabiskan waktu hampir enam setengah jam setiap harinya bersama media. Siswa adalah seorang pengguna multimedia, sambil menonton televisi siswa bisa mengirim pesan singkat dan menyelesaikan pekerjaan rumah. Ketika bermain video game, biasanya bekerja sebagai anggota kelompok dan dengan konsentrasi tinggi bahkan dalam waktu lama, menyelesaikan sebuah proyek yang memakan waktu lama. Siswa mencari informasi melalui Internet, menampilkan dirinya di media sosial, dan mengambil gambar dari ponselnya, dan kemudian memilih beberapa situs umum berupa media sosial. Secara bersamaan mereka juga dapat berperan sebagai aktor, sutradara, editor, dan penerbit dengan perangkat lunak film yang berasal dari komputer. Mereka mengharapkan guru untuk membimbingnya melalui era informasi ini, bukan mendiktenya atas jawab "benar" atas pertanyaan ulangan yang Google dapat segera sediakan dalam hitungan detik melalui alat bantu multimodal, misalnya teks, video, dan gambar-gambar digital (Schrum, 2013). Selain itu menurut Cooke (2017) baru-baru ini, media sosial dan situs jejaring menjadi semakin populer sebagai sumber belajar dan mengajar di pendidikan tinggi, memberikan kesempatan yang lebih besar kepada siswa untuk terlibat dalam pendidikan. Dengan demikian perlu memanfaatkan perkembangan teknologi dalam pembelajaran terutama media pembelajarannya, dalam hal ini media berbasis web e-learning.

Menurut Media pembelajaran berbasis online adalah salah satu bentuk pemanfaatan teknologi informasi dalam bentuk internet dalam pembelajaran, salah satunya dalam pembelajaran Pendidikan Kewarganegaraan (PKn). Namun, ada beberapa masalah dalam menggunakan internet dalam pembelajaran (Hanum, Komalasari, \& Masyitoh, 2018), seperti siswa sekolah menengah yang pernah menggunakan ponsel untuk mengirim kunci jawaban selama ujian kepada siswa lain; siswa telah menggunakan SMS atau tangga sosial untuk mengintimidasi/mengolok-olok siswa lain. Selain itu, sebagian besar siswa telah menyalin informasi yang diperlukan dari internet dan telah menggunakan gadget / android, sebuah game online selama pelajaran kelas. Secara positif, mereka menggunakan gadget dengan fasilitas internet di kelas sebagai sumber belajar ketika siswa ingin menemukan sumber belajar yang tidak ada dalam buku paket. Para siswa mengklaim membutuhkan bahan ajar/media alternatif yang dapat digunakan untuk mempelajari konsep-konsep dalam kewarganegaraan jauh lebih mudah dan menarik serta siswa sepakat ketika diperlukan untuk mengembangkan media pembelajaran berbasis online untuk memberikan konsep pengajaran dalam kewarganegaraan sehingga konsep tersebut mudah untuk memahami. Selain itu, dapat mendukung tujuan pendidikan kewarganegaraan untuk menanamkan dan mengaktualisasikan nilai-nilai Pancasila dalam kehidupan berbangsa dan bernegara yang tercermin dalam karakter bangsa Indonesia. Oleh karena itu perlu untuk mengembangkan media pembelajaran berbasis online dalam Pendidikan Kewarganegaraan pada siswa SMA.

Dengan demikian dalam artikel ini membahas bagaimana konsep media web Moodle tersebut, bagaimana ciri-cirinya dan mengapa memilih media tersebut. Selain itu, dibahas pula bagaimana model pembelajaran yang sesuai. 


\section{METODE PENELITIAN}

Metode yang digunakan dalam penelitian ini adalah metode penelitian diskriptif dengan pendekatan kualitatif. Menurut Sugiyono (2005) menyatakan bahwa metode deskriptif adalah suatu metode yang digunakan untuk menggambarkan atau menganalisis suatu hasil penelitian. Metode deskriptif adalah pencarian fakta dengan interpretasi yang tepat. Teknik pengumpulan datanya adalah kajian pustaka atau literatur.

\section{HASIL DAN PEMBAHASAN}

\section{Konsep Media Pembelajaran Web Moodle}

Sebelumnya dikaji tentang pengertian dari media pembelajaran tersebut yaitu kata media berasal dari bahasa Latin medius yang secara harfiah berarti tengah, perantara dan pengantar. Dalam Bahasa Arab media adalah perantara atau pengantar pesan dari pengirim ke penerima pesan. Banyak batasan yang diberikan orang tentang media. Asosiasi Teknologi dan Komunikasi Pendidikan (Association of Education and Communication Technology/AECT) di Amerika, membatasi media sebagai segala bentuk dan saluran yang digunakan orang untuk menyalurkan pesan/informasi. Gagne (1970) menyatakan bahwa media adalah berbagai jenis komponen dalam lingkungan siswa yang dapat merangsangnya untuk belajar. Sementara itu Briggs \& Wager (1981) berpendapat bahwa media adalah segala alat fisik yang dapat menyajikan pesan serta merangsang siswa untuk belajar. Buku, film, kaset, film bingkai adalah contoh-contohnya (Sadiman et al., 2008).

Danial \& Djuherman (2017) mengungkapkan media merupakan konsep komunikasi yang berperan sebagai alat penyampaian pesan dari komunikator (penyampai pesan) kepada komunikan (penerima pesan) agar dapat dipengaruhi. Banyak sekali alat itu digunakan seiring dengan perkembangan manusia dalam masyarakat serta ilmu pengetahuan dan teknologi sejak manusia ada dari yang tradisional sampai modern. Pentahantan mengenai konsep media sebagai alat komunikasi, amat berpengaruh terhadap perkembangan pendidikan, sebab konsep pendidikan bisa terjadi apabila terjadinya interaksi antara pendidik dan peserta didik.

Dengan demikian melihat pengaruhnya media di dalam pendidikan maka dikenal media pembelajaran. Media pembelajaran telah didefinisikan sejak lama oleh Raiser dan Gagne (1983) dalam (Reiser, 2001) "the term instructional media has been defined as the physical means via which instruction is presented to learners". Di bawah definisi ini, setiap sarana fisik pengiriman instruksional, dari instruktur langsung ke buku teks ke komputer dan sebagainya, diklasifikasikan sebagai media pembelajaran. Dengan demikian media pembelajaran sebagai sarana fisik yang memberikan arahan kepada peserta didik, berkaitan dengan alat yang digunakan dalam proses pembelajaran.

Menurut Kemp dan Dayton (1985, hal. 28), media pembelajaran dapat memenuhi tiga fungsi utama apabila media itu digunakan untuk perorangan, kelompok, atau kelompok yang besar jumlahnya, yaitu dalam hal (1) memotivasi minat atau tindakan, (2) menyajikan informasi, dan (3) memberi instruksi. Untuk memenuhi fungsi motivasi, media pembelajaran dapat direalisasikan dengan teknik drama atau hiburan. Sedangkan untuk tujuan informasi, media pembelajaran dapat digunakan dalam rangka penyajian

\section{JURNAL KEWARGANEGARAAN}


informasi di hadapan sekelompok siswa. Isi dan bentuk penyajian bersifat sangat umum, berfungsi sebagai pengantar, ringkasan laporan, atau pengetahuan latar belakang. Penyajian dapat pula berbentuk hiburan, drama, atau teknik motivasi.

Media pembelajaran mempunyai banyak jenis dan bentuknya. Dalam pembelajaran diperlukan pengetahuan dan ketepatan dalam memilih jenis media yang cocok diterapkan. Rudy Bretz dalam Sadiman, Rahardjo, Haryono, \& Harjito (2008) mengidentifikasikan ciri utama dari media menjadi tiga unsur pokok, yaitu suara, visual dan gerak. Media visual sendiri dibedakan menjadi tiga, yaitu: gambar, garis, dan simbol, yang merupakan suatu bentuk yang dapatditangkap dengan indera penglihatan. Di samping ciri tersebut, Bretz juga membedakan antara media siar (telecomunication) dan media rekam (recording), sehingga terdapat delapan klasifikasi media, yaitu: (1) media audio visual gerak, (2) media audio visual diam, (3) media visual gerak, (4) media visual diam, (5) media semi gerak, (6) media audio, dan (7) media cetak.

Sedangkan media yang dipergunakan dalam proses belajar mengajar terdapat 13 macam menurut Briggs \& Wager (1981, hal. 23) yaitu: obyek, model, suara langsung, rekaman audio, media cetak, pembelajaran terprogram, papan tulis, media transparansi, film rangkai, film bingkai, film, televise dan gambar. Kemudian Gagne membuat 7 macam pengelompokan media yaitu: Benda untuk didemontrasikan, komunikasi lisan, media cetak, gambar diam, gambar gerak, film bersuara, mesin belajar. Sedangkan menurut Edling media merupakan bagian dari enam unsur rangsangan belajar, yaitu dua untuk pengalaman audio meliputi kodifikasi subyektif visual dam kodifikasi obyektif audio, dua untuk pengalaman visual meliputi kodifikasi obyektif audio dan kodifikasi obyektif visual dan dua pengalaman belajar 3 dimensi meliputi pengalaman langsung dengan orang dan pengalaman langsung dengan benda-benda (Sadiman et al., 2008).

Menurut Sadiman, Rahardjo, Haryono, \& Harjito (2008) kriteria pemilihan media harus dikembangkan sesuai dengan tujuan yang ingin dicapai, kondisi dan keterbatasan yang ada dengan mengingat kemampuan dan sifat-sifat khasnya (karakteristik) media yang bersangkutan. Menurut Komalasari \& Saripudin (2017b, hal. 211) dalam memilih media, perlu diperhatikan seperti apa pesan yang akan disampaikan, bagaimana pesan disampaikan, bagaimana ciri-ciri materi pelajaran (afektif, psikomotorik, atau kognitif), pertimbangan jumlah siswa, kemampuan produksi, dan merencanakan pengembangan dan produksi media tersebut. Selain menyampaikan informasi diharapkan media pembelajaran mampu menumbuhkan motivasi dan simpati siswa untuk mengembangkan sikap dan keterampilan. Jadi media pembelajaran tidak hanya sekadar membantu kognitif siswa tetapi juga bertujuan mengembangkan afektif dan psikomotorik siswa.

Konseptual model media web Moodle ini berupa multimedia berbasis digital web. Dikatakan multimedia karena karakteristik dari media web Moodle ini di dalamnya berisi kombinasi dari berbagai media. Menurut Arsyad (2014) dalam Komalasari \& Saripudin (2017b) multimedia yang umumnya dikenal dewasa ini merupakan kombinas dari grafis, teks, suara, video dan animasi. Di sisi lain Vaughan menjelaskan bahwa multimedia adalah sembarang kombinasi yang terdiri dari teks, seni grafik, bunyi, animasi, dan video yang diterima oleh pengguna melalui komputer. Dapat disimpulkan bahwa multimedia adalah kombinasi dari teks, foto, seni grafis, animasi yang dimanipulasi secara digital.

Dengan demikian dapat diketahui karakteristik dari media web Moodle tersebut berdasar pada karakteristik multimedia interaktif menurut Sucipta dalam Komalasari \& Saripudin (2017a) antara lain: 
1. Memiliki lebih dari satu media yang konvergen (misalnya menggabungkan unsur audio dan visual). Media Web Moodle bersifat konvergen karena di dalamnya menngabungkan unsur audio dan visual berupa video dan teks.

2. Bersifat interaktif dalam pengertian memiliki kemampuan untuk mengakomodasi respon pengguna. Media Web Moodle ini memenuhi karakteristik tersebut dilihat dari memberikannya fasilitas chat dan diskusi antarpengguna yaitu antarsiswa maupun antara siswa dan guru. Selain itu juga dilengkapi dengan kuis yang langsung merespon hasil kerjaan siswa.

3. Bersifat mandiri dalam pengertian memberikan kemudahan dan kelengkapan isi sedemikian rupa sehingga pengguna bisa menggunakan tanpa bimbingan orang lain. Dalam hal ini siswa dapat menggunakan media web Moodle secara mandiri dengan mengikuti petunjuk yang ada.

Bentuk media pembelajaran berbasis web Moodle dalam PPKn adalah dalam bentuk web pembelajaran. Setelah melalui tahapan pengembangan sampai dievaluasi maka kemudian media ini diterapkan atau diimplementasikan dalam pembelajaran untuk mengetahui kelayakan dan kualitas media. Jika media tersebut layak menurut guru dan siswa maka media dapat dimanfaatkan untuk mendukung proses pembelajaran, dalam hal ini adalah pada mata pelajaran Pendidikan Pancasila dan Kewarganegaraan.

Sebelum diimplementasikan dalam pembelajaran, media pembelajaran web Moodle ini dilakukan validasi terhadapnya, yaitu validasi oleh ahli media dan ahli materi. Hasil validasi ahli media dan ahli materi menyatakan bahwa media pembelajaran web Moodle ini layak diujicobakan ke dalam pembelajaran PPKn di SMA dengan beberapa revisi. Setelah direvisi kemudian diimplementasikan ke sekolah dan mendapatkan penilaian dari guru telebih dahulu, selanjutnya diujicobakan kepada kelas uji coba terbatas.

Hasil akhir dari validasi dan penilaian dari guru adalah bentuk web pembelajaran yang terdiri dari beberapa menu. Menu home yaitu tampilan awal dari web ketika pertama kali dibuka. Kemudian menu kedua yang dibuka adalah menu login dan course dimana dalam menu ini memberikan akses kepada siswa dan guru memilih course atau bidang yang akan dipelajari kemudia masuk ke dalam category course dan berupa lesson, siswa masuk ke dalam setiap lesson. Menu lesson ini berupa subsansi dari web dimana berisi materi yang berupa teks, gambar dan video. Selanjutnya web juga dilengkapi dengan menu evaluasi.

\section{Konsep Pembelajaran dengan Menggunakan Media Web Moodle}

Media web Moodle ini ditujukan untuk dimanfaatkan dalam pembelajaran Pendidikan Kewarganegaraan di SMA kelas XI. Pemanfaatan tersebut menggunakan model blended learning. Dari pembahasan di kajian teori blended learning dalam pemanfaatan web ini adalah pembelajaran campuran yaitu pengajaran yang menggabungkan dan mencocokkan berbagai situasi pengajaran agar sesuai dengan kebutuhan belajar siswa, dalam hal ini guru haus paham kapan efektif bagi siswa untuk berada dalam situasi fisik actual bersama guru dan kapan mereka bisa mereka bisa bekerja lebih mandiri atau menggunakan pembelajaran online (Smaldino, Lawther, \& Russell, 2011). Sedangkan waktu dan porposi penggunaan pembelajaran campuran adalah bersifat fleksibel, tetapi yang menjadi ciri utama adalah penggunaan pembelajaran online dimana memanfaatkan internet.

\section{JURNAL KEWARGANEGARAAN}


Blended learning adalah suatu pendekatan yang fleksibel untuk merancang program yang mendukung campuran dari berbagai waktu dan tempat untuk belajar. Menurut Rovai and Jordan dalam Syarif (2012) model blended learning pada dasarnya merupakan gabungan keunggulan pembelajaran yang dilakukan secara tatap muka (face to face learning) dan secara virtual (e-learning). Pembelajaran online atau e-learning dalam blended learning menjadi perpanjangan alami dari pembelajaran ruang kelas tradisional yang menggunakan model tatap muka (face to face learning).

Pemanfaatan dalam pembelajaran adalah dengan memanfaatkan laboratorium komputer. Langkah-langkah peanfaatannya adalah sebagai berikut:

1. Guru meminta salah satu peserta didik untuk memimpin berdoa.

2. Guru mengondisikan suasana belajar yang menyenangkan di dalam laboratorium komputer, karena siswa tertarik dan antusias dengan belajar di luar kelas seperti misal di laboratorium komputer. Setelah itu guru menjelaskan tujuan pembelajaran pada pertemuan ini, yaitu mengulang pembelajaran dan meminta siswa menggunakan media web Moodle untuk menganalisis kasus-kasus yang telah ada di web, kemudian membaca materinya dan berdiskusi di dalam web.

3. Guru menyampaikan kompetensi yang akan dicapai, yaitu mengkaji kasus-kasus ancaman terhadap Ipoleksosbudhankam dalam bingkai Bhinneka Tunggal Ika dan manfaatnya dalam kehidupan sehari-hari, guru dapat mendiskusikan manfaat yang diperoleh dengan mempelajari materi, pada kompetesi dasar ini.

4. Guru menyampaikan garis besar cakupan materi yaitu mewaspadai ancaman terhadap kedudukan Negara Kesatuan Republik Indonesia, siswa diminta membuka web moodle dan log in kemudian masuk ke dalam lesson 1 yaitu mengatahui latar belakang mengapa harus mewaspadai ancaman terhadap Kedudukan NKRI.

5. Guru menyampaikan lingkup dan teknik penilaian yang digunakan yaitu penilaian sikap, pengetahuan dan keterampilan. Penilaian sikap dilakukan dengan cara observasi selama proses pembelajaran terutama sikap jujur dan tanggung jawab, penilaian pengetahuan berupa penugasan sedangkan penilaian keterampilan berupa kemampuan siswa dalam menyajikan hasil diskusi di dalam web.

6. Siswa diminta untuk masuk ke lesson satu mengamati tayangan video yang berkaitan dengan ancaman terhadap ipoleksosbudhankam dalam bingkai BhinnekaTunggal Ika dan materi lainnya.

7. Siswa belajar secara mandiri sampai mencapai lesson terakhir.

8. Peserta didik mengidentifikasi sekaligus mencatat pertanyaan yang ingin diketahui dari apa yang telah dibacanya dan bisa menuliskan di menu diskusi atau chat. Hal ini bisa ditanggapi oleh siswa lainnya maupun gurunya. Selain melalui web siswa juga bisa lansung menanyakan kepada gurunya, karena pada pembelajaran ini tidak menggantikan tatap muka.

\section{SIMPULAN}

Konsep model media web Moodle ini berupa multimedia berbasis digital web. Dikatakan multimedia karena karakteristik dari media web Moodle ini di dalamnya berisi kombinasi dari berbagai media. Bentuk dari media berbasis web Moodle ini dalam bentuk 
halaman web. Dalam pemanfaatannya berupa langkah-lngkah pemanfaatan media web Moodle dalam pembelajaran PPKn yang dilaksanakan di laboratorium computer dengan model pembelajaran blended learning. Guru melakukan kegiatan pendahuluan di kelas dan menyampaikan pembelajaran dengan menggunakan media web. Kemudian siswa login ke dalam web dan masuk ke dalam lesson satu dan seterusnya, analisis kasus sampai dengan uji kompetensi. Jika ada pertanyaan maka bisa membuka menu diskusi dan berdiskusi dengan teman lainnya beserta guru.

\section{UCAPAN TERIMA KASIH}

Penulis mengucapkan terima kasih yang sebesar-besarnya kepada Lembaga Pengelola Dana Pendidikan (LPDP) atas dukungannya terhadap penelitian Fathikah Fauziah Hanum.

\section{DAFTAR PUSTAKA}

Abdulhak, I., \& Darmawan, D. (2015). Teknologi Pendidikan. Bandung: Rosdakarya.

Alty, J. L., Al-Sharrah, A., \& Beacham, N. (2006). When Humans form Media and Media form Humans: An Experimental Study Examining the Effects Rifferent Digital Media Mave on the Learning Outcomes of Students Who Have Different Learning Styles. Interacting with Computers, 18(5), 891-909. https://doi.org/10.1016/j.intcom.2006.04.002

Briggs, L. J., \& Wager, W. W. (1981). Handbook of Procedures for the Design of Instruction. New Jersey: Educational Technology.

Cooke, S. (2017). Social teaching: Student Perspectives on the Inclusion of Social Media in Higher Education. Education and Information Technologies, 22(1), 255-269. https://doi.org/10.1007/s10639-015-9444-y

Danial, E. \& Djuherman. (2017). Pengembangan Kurikulum Pendidikan Kewarganegaraan. Harapan Cerdas Publisher.

Hanum, F. F., Komalasari, K., \& Masyitoh, I. S. (2018, November 1). The Need of Instructional Media Online for Senior High School Students in Civic Education. In Annual Civic Education Conference (ACEC 2018). Atlantis Press. https://doi.org/10.2991/acec-18.2018.37

Komalasari, K., \& Saripudin, D. (2017a). Pendidikan Karakter: Konsep dan Aplikasi Living Values Education. Bandung: Refika Aditama.

Komalasari, K., \& Saripudin, D. (2017b). Value-Based Interactive Multimedia Development through Integrated Practice for the Formation of Students' Character. Turkish Online Journal of Educational Technology-TOJET, 16(4), 179-186.

Kustandi, C., \& Sutjipto, B. (2011). Media Pembelajaran: Manual dan Digital. Bogor: Ghalia Indonesia.

Reiser, R. A. (2001). A History of Instructional Design and Technology: Part I: A History of Instructional Media. Educational Technology Research and Development, Vol. 49, 53-64. https://doi.org/10.1007/BF02504506

\section{JURNAL KEWARGANEGARAAN}


Sadiman, A. S., Rahardjo, R., Haryono, A., \& Harjito. (2008). Media Pendidikan: Pengertian Pengembangan dan Pemanfaatannya. Jakarta: Raja Grafindo Persada.

Schrum, L. (Ed). (2013). Teknologi Pendidikan bagi Para Pemimpin Sekolah. Jakarta: Indeks.

Smaldino, S. E., Lawther, D. L., \& Russell, J. D. (2011). Instructional Technology and Media for Learning: Teknologi Pembelajaran dan Media untuk Belajar (B. S. Triwibowo, Ed.; A. Rahman, Penerj.). Jakarta: Kencana.

Sugiyono. (2012). Metode Penelitian Kuantitatif, Kualitatif dan $R \& D$. Bandung: Alfabeta.

Syarif, I. (2012). Pengaruh Model Blended Learning Terhadap Motivasi dan Prestasi Belajar Siswa SMK. Jurnal Pendidikan Vokasi, 2(2), 234-249. https://doi.org/10.21831/jpv.v2i2.1034 
